\title{
RADIKALISME DALAM PERSFEKTIF ISLAM DAYAH DI ACEH
}

\author{
Rizki Yunanda, ${ }^{1}$ Subhani ${ }^{2}$ \\ Fakultas Ilmu Sosial dan Ilmu Politik, Universitas Malikussaleh \\ rizkiyunanda56@gmail.com
}

\begin{abstract}
ABSTRAK
Penelitian ini bertujuan membahas tentang perfektif Islam dayah terhadap radikalisme. Penelitian ini dilaksanakan di dayah di Lhokseumawe. Jenis penelitian ini menggunakan penelitian kualitatif dengan teknik pengumpulan data yaitu observasi, wawancara, dan studi dokumen. Hasil penelitian ini menunjukkan bahwa Islam dayah menegaskan Istilah radikalisme dan terorisme adalah samatan oleh golongan anti Islam. Islam agama yang mengajarkan cinta damai dan rukun terhadap umat beragama. Karena itu tindakan radikalisme tidak dilakukan oleh yang beragama Islam, namun dilakukan oleh oknum yang mengatasnamakan Islam, selain itu radikalisme juga merupakan ciptaan atau peranakkan oleh sekelompok kepentingan yang ingin mengkotak-kotakkan Islam, bunuh diri tidak ada dalam Islam, bunuh diri adalah paham sesat yang memamfaatkan kebodohan masyarakat awam terhadap pengetahuan tentang Agama. Kebanyakan terikontamidasi dengan pemahaman sesat dalam pergerakan mengatasnamakan jihad. buktinya pergerakan Jama'ah Islamiyah Indonesia yang berkembang di Aceh tahun 2010. Tidak ada ulama Aceh terlibat ketika itu, sebaliknya para ulama mengeluarkan fatwa dan sepakat untuk menolak kehadiran kelompok yang dianggap sesat dan menyimpang di Aceh.
\end{abstract}

Kata Kunci: Radikalisme, Persfektif, Islam Dayah, Aceh. 
Vol.2, No.2, November Tahun 2019

\section{PENDAHULUAN}

Isu radikalisme, terorisme, deskriminasi, dan sikap intoleran kembali mencuat sebagai isu paling populis di Indonesia saat ini. Sinaga, dkk (2017) mengatakan radikalisme muncul dari pemahaman agama yang tertutup (baca: fanatik) dan tesktual (baca: kaku) sehingga merasa kelompoknya yang paling benar, sedangkan kelompok yang lain dianggap kafir atau sesat. Abidin (2014: 245) menyebutkan tindakan radikalisme di dunia menjadi aktual terutama sejak terjadinya peristiwa Word Trade Center (WTC) di New York, Amerika Serikat pada 11 September 2001 yang menelan korban lebih dari enam ribu jiwa termasuk ratusan kaum muslimin yang tidak berdosa. Sejak itu pula cap terorisme dialamatkan kepada umat Islam, prasangka dan stereotip Barat yang sampai saat ini masih belum berubah secara keseluruhan. Padahal menurut Amstrong, dalam (Abidin, 2014: 234) bahwa Islam memang mempunyai kelompok fundamentalis; namun begitu juga setiap agama besar di dunia. Ada Budha fundamentalis, konfusianis mentalis, Hindu fundamentalis, Kristen fundamentalis, Yahudi fundamentalis. Fundamentalis merupakan suatu fenomena yang selalu muncul dalam setiap agama besar dunia. Kelompok fundamentalis inilah yang terkadang muncul menjadi kelompok garis keras dan mengarah kepada terorisme.

Data Badan Nasional Penanggulangan Terorisme (BNPT) Republik Indonesia Tahun 2016, Provinsi Aceh adalah salah satu dari 12 provinsi yang rawan akan paham radikalisme di Indonesia. Pasca 14 tahun konflik dan perdamaian Aceh, berbagai isu kembali mencuat di tengah rasa aman dan kondusif. Munculnya diskursus Khilafah, Negara Islam, Jihad, bay'at dan kajian tentang Piagam Madinah dan Negara Madinah yang secara terus menerus didiskusikan dan di prakarsai oleh kelompok-kelompok kecil yang mengatasnamakan Islam. Sebagai daerah bekas konflik, Aceh menjadi daerah yang super layak dalam perjuangan mendeklarasikan kaum radikal fundamentalis dan teoritis termasuk bagaimana menyelewengkan penafsiran dan interpretasi makna jihad untuk merasuk pola pikir masyarakat Aceh yang di kenal gigih dalam berperang. Tidak tertutup kemungkinan, gerakan-gerakan tersebut terus bergerilya masuk kedalam lembaga-lembaga pendidikan dayah di Aceh untuk mengubah pemikiran tradisional dayah yang selama ini telah hidup berangsur lama tanpa terpengaruhi oleh idiologi-idiologi radikal.

Dayah merupakan lembaga pendidikan tertua di Aceh, jauh sebelum lahirnya lembaga pendidikan formal pada umumnya yang berkembang saat ini, perkembangan 
tradisional dayah salafi telah melahirkan para lulusan-lulusan terbaik dalam bidang keagamaaan yang tersebar di seluruh sendi-sendi kehidupan masyarakat hingga dikenal sebagai ulama dayah. Amiruddin (2013) mengatakan Ulama Dayah (ulama pesantren) merupakan suatu kelompok istimewa di antara ulama dan cendekiawan Aceh. Mereka lulusan dari Dayah dan oleh karena itu mereka lebih terhormat diantara orang yang menuntut ilmu di tempat lain. Kekuatan ulama Dayah secara normatif semakin bersifat afirmatif di dalam culture masyarakat Aceh. Namun demikian ketakutan besar menghampiri para ulama dayah akan berbagai tuduhan islamophobia dan radikalisme di justifikasi sebagai landasan tindak kekerasan radikal.

Konflik Aswaja (Ahlussunnah Waljama'aah) atau pemikiran Islam dayah dengan salafi wahabi merupakan suatu fenomena merebaknya pertentangan mazhab di Aceh dalam melawan paham radikal, awalnya sama-sama menghargai, menerima perbedaan, toleransi, kerjasama inklusif dan memaklumi persoalan khilafiyah. Kini kedua kelompok terlihat sama-sama memperlihatkan kekuatan dan resistensi masing-masing kelompok. Aswaja yang di pelopori oleh kalangan pemikiran Islam dayah sedangkan kelompok salafi wahabi Aceh umumnya di persepsikan oleh kalangan Islam dayah adalah kalangan sekelompok golongan yang memahami ilmu-ilmu keislaman dari timur tengah dan memadukannya dengan ilmu pengetahuan modern di kampus-kampus. Para ulama dayah menghendaki agar jejak salafi wahabi harus dihapuskan di Aceh karena selama ini dianggap sering membid'ahkan bahkan mengkafirkan sesama Islam yang mengakibatkan pada tindakan radikalisme dan ekstrimisme.

Ulama dayah menentang keras penyebaran pemahaman Islam oleh kelompok salafi wahabi di Aceh. Bagi ulama Dayah kelompok wahabi cenderung bersikap ekstrim dan radikal. Umumnya mereka mudah membid'ahkan bahkan mengkafirkan siapapun. Beberapa permasalahan anatar Islam dayah dan kelompok tersebut nyakni, menolak perayaan maulid, menolak ziarah kubur (Istigasah), tidak mengakui qunut dan mengganggap orang yang diluar kelompok mereka sesat. Menurut Syaikh Muhammad bin Jamil Zainu dalam Al-Chaidar (2017: 452) Wahabi adalah paham keagamaan yang dianut kalangan yang tidak suka kepada adat-istiadat dan kebiasaan yang menyimpang yang mengharap kekuatan leluhur, melanggar tradisi adat, tidak mau ikut maulidan Nabi, tidak percaya kepada sunan, wali dan keramat-keramatnya, anti tahyul, khurafat dan bid'ah. Kata Wahabi adalah nisbat kepada Muhammad bin Abdul Wahab. Kelompok ini terlalu berani 
dalam menumpahkan darah atas alasan asaz jihad. Sehingga para ulama dayah sepakat untuk menolak paham dari kelompok yang dianggap beraliran salafi wahabi di Aceh.

\section{METODOLOGI}

Metode penelitian yang digunakan dalam studi ini adalah metode kualitatif tentang radikalisme. Penelitian kualitatif dilakukan pada kondisi alamiah dan bersifat penemuan" (Iskandar, 2009). Penelitian kualitatif sebagai human instrument, berfungsi menetapkan fokus penelitian, memilih informan sebagai sumber data, menilai kualitas data, analisis data, menafsirkan data dan membuat kesimpulan atas semuanya. Metode kualitatif ini bersifat terbuka dan dinamis sehingga memungkinkan informan untuk mengungkapkan pengalamannya dengan terbuka. Dalam penelitian ini, metode kualitatif dianggap peneliti mampu mengkaji persfektif radikalisme dari kalangan Islam dayah di Aceh.

Studi ini dilakukan di beberapa dayah di Lhokseumawe. Dalam hal ini penulis menganalisis radikalisme dalam perfektif Islam dayah. Menggunakan kerangka pemikiran Berger yang mengacu pada tiga poin penting makna yang dimiliki aktor sosial, yakni: semua manusia memiliki makna dan berusaha untuk hidup dalam dunia yang lebih bermakna. Karena kehidupan manusia bukan hanya dapat dipahami oleh sendirinya, tetapi juga dapat dipahami oleh orang lain. Terdapat beberapa katagori. Pertama, makna secara langsung yang dapat digunakan dalam kehidupan sehari-hari dan makna yang tidak dapat secara langsung dipakai secara praktis. Kedua, makna dapat dibedakan menjadi makna dari tafsiran orang awam, dan makna hasil tafsiran ilmuan sosial. Ketiga, makna yang diperoleh dari interaksi tatap muka dan makna yang diperoleh tidak dengan interaksi (misalnya melalui media massa). Karena itu, Berger menjadikan interaksi sosial sebagai subject matter sosiologi. Interaksi ini melibatkan hubungan individu dengan masyarakat. Individu adalah acting subject, makhluk hidup yang senantiasa bertindak dalam kehidupan sehariharinya.

Tulisan ini menceritakan mengenai radikalisme dalam perspektif Islam dayah di Aceh. Topic tulisan ini kemudian dikaji melalui pendekatan kualitatif secara deskriptif, dimana informasi yang bersifat kualitatif dideskripsikan secara teoritis dan analitis. Tulisan ini menjelaskan radikalisme dalam persfektif tradisional dayah salafi. Selain aspek tersebut peneliti juga menguraikan apakah ada kaitan antara wahabi dan radikalisme. Informasi yang diperoleh dalam tulisan ini diperoleh dari tempat penelitian Kota Lhokseumawe, Provinsi Aceh. Alasan memilih lokasi ini disebabkan oleh beberapa hal seperti Pertama, 
Peneliti memilih dengan pertimbangan bahwa dibandingkan dengan daerah lain di Aceh, Lhokseumawe menjadi salah satu Kota transit dan kota berkembang di Aceh saat ini, selain itu keberadaan beberapa Universitas Negeri di Lhokseumawe telah mengundang para mahasiswa untuk menjadi mahasiswa menetap, yang bukan hanya menetap di rumah kos, namun juga sebagian ada yang menetap di Lembaga pendidikan dayah tradisional dayah (pesantren) yang setiap pagi hari aktif sebagai mahasiswa dan pada malam harinya aktif sebagai santri. Sasaran atau objek dari penelitian ini adalah pimpinan Dayah dan santri di Kota Lhokseumawe. sedangkan informan dalam penelitian ini adalah subjek yang memahmi informasi dari objek penelitian. Peneliti memperoleh data dan informasiinformasi tentang radikalisme dari para informan.

\section{HASIL PEMBAHASAN}

Peran gerakan fundamentalis yang mengatasnamakan Islam, menebar idiologi radikal yang sangat berpengaruh dalam aksi "jihadist" kelompok yang beridiologi ekstrim dan hanya butuh hitungan menit mendoktrinasi pemikiran sasaran (masyarakat) menjadi para simpatisan dari awalnya hanya partisipan untuk mau mengorbankan diri dalam setiap aksi radikal. Proses indoktrinasi yang begitu cepat dan tidak butuh waktu lama hanya berkisar waktu 15 dan 25 menit untuk siap menjadi pengantin (bom bunuh diri). Aksi fundamentalis radikal ini gencar diasosiakan kedalam masyarakat dengan dalih jihad. Konsep jihad menyimpang inilah dikonsepsikan oleh sebagian orang untuk melakukan tindak kekerasan dan radikalisme. Maka untuk itu penulis ingin mengutarakan niatnya untuk mengetahui radikalisme dalam perfektif dayah tradisional salafi di Aceh dalam mengeksternalisasi ajaran-ajaran jihad sehingga memastikan apakah konsep radikalisme benar-benar tidak berkembang dalam masyarakat saat Aceh saat ini.

Menurut Sahrasad (2017: 510), sejarah kekerasan dan radikalisme seringkali membawa nama Agama. Hal ini dapat dipahami karena agama memiliki kekuatan yang dahsyat, yang melebihi kekuatan politik, sosial dan budaya. Agama bahkan bisa diangkat sampai pada tingkat supranatural. Atas nama agama, kemudian radikalisme diabsahkan dalam berbagai tindakan. Mulai dari mengkafirkan orang-orang yang tak sepaham (takfir) sampai melakukan pembunuhan terhadap musuh yang tidak seideologi dengannya.

Pandangan stereotipikal Islam dengan radikalisme semakin meningkat, dan juga membangkitkan kembali gelombang Islamofobia, baik dalam hal agama, budaya, maupun politik di kalangan masyarakat Eropa, Amerika dan Australia. Islam dan umat Islam 
menjadi yang tertuduh dari berbagai aksi tersebut, berbagai stigma dilekatkan bahwa Islam identik dengan radikalisme, terorisme dan kekerasan. Stigma ini seakan membenarkan beberapa pandangan pemikiran Barat. yang melihat Islam sebagai ancaman setelah runtuhnya Soviet, sebagaimana tesis Samuel Huntington tentang clash of civilization (benturan peradaban) (Al-Chaidar, 2017: 510).

Ayat-ayat al-Quran yang seringkali disalahpahami dan dijadikan dalil bagi tindakantindakan radikal adalah ayat-ayat jihad dan ayat-ayat perang. Karena itu, menjadi penting untuk memahami ayat-ayat tersebut sesuai dengan konteks dan maksud pensyariatannya. Bagi sebagian kelompok radikal, jihad terkadang diartikan perang melawan musuh Islam, sehingga tindakan kekerasan terhadap segala sesuatu dianggap sebagai musuh Islam dan merupakan perbuatan jihad yang mulia. Akibatnya kata jihad menjadi sesuatu yang mengerikan, dan mengakibatkan Islam menjadi tertuduh. Islam dipandang oleh non muslim dan Barat sebagai agama teroris. Sehingga tidak berlebihan jika dikatakan bahwa istilah jihad merupakan salah satu konsepsi Islam yang paling sering disalahpahami, khususnya di kalangan para ahli dan pengamat Barat. Padahal jika kita telusuri kata jihad dalam Al-Quran sebagaimana akan dijelaskan dalam paparan berikut berbeda dengan radikalisme dan peperangan. Jihad selain merupakan salah satu inti ajaran Islam, juga tidak bisa disederhanakan dan diindentikkan dengan perang (qitāl). Perang selalu merujuk kepada pertahanan diri dan perlawanan yang bersifat fisik, sementara jihad memiliki makna lebih luas. Di sisi lain, qitāl sebagai terma keagamaan baru muncul pada periode Madinah, sementara jihad telah menjadi dasar teologis sejak periode Mekah.

\section{Radikalisme Disamatkan dan Bukan Ajaran Islam}

Dalam tradisi berfikir masyarakat Aceh menurut Bustamam (2016: 189) menyebutkan kosep musoh (lawan) dianggap sebagai pengkhianatan atas apa selama ini tidak menjadi persoalan, dalam masyarakat Aceh, musoh dianggap mengganggu $\mathrm{Din} \mathrm{Al}$ Islam. Karena itu konsep musoh saat ini bukan lagi kaphe (kafir) tetapi termasuk orang Islam yang berkhianat kepada agama atau orang yang menghalangi pelaksanaan hukum Islam di Aceh sehingga sebagiannya dipanggil dengan julukan si PAI (Pengkhianat Agama Islam). Alasan tersebut menguatkan bahwa radikalisme tidak berkembang di Aceh. Menguatnya alasan tersebut pasca penangkapan jaringan teroris yang melakukan latihan di Jantho tahun 2010. 
Dalam konteks ini pula, ulama dayah Aceh menyatakan sebutan radikalisme itu hanya desain global, yang dikonstruksikan menjadi sebuah realitas objektif lewat penyimpangan-penyimpangan yang dilakukan oleh sekelompok aliran atau sekte yang mengatasnamakan Islam. Serangan yang secara terus-menerus digencarkan oleh kelompok tersebut membuat peran para ulama untuk memperbaiki nama baik Islam terus menuai kesulitan dan ancaman untuk membangun landasan berfikir kembali bahwa radikalisme itu bukan ajaran yang bersumber dari Islam.

Radikalisme agama memiliki dampak yang luas bagi segala sendi kehidupan sebagaimana yang dikatakan oleh M. Nuh (2009: 38-39) pada tataran kehidupan berbangsa dan bernegara gerakan radikalisme memang nampak cukup merepotkan para penguasa, terutama karena beberapa alasan: Pertama, gerakan radikalisme sering dinilai sebagai gerakan yang berkepentingan untuk mengganti ideologi negara yang sudah mapan dengan ideologi kelompok gerakan radikal tersebut, tanpa mempertimbangkan kepentingan ideologi kelompok lain yang berbeda dengannya. Kedua, gerakan radikalisme di anggap membawa instabilitas sosial, keresahan sosial, terutama karena sifat gerakan tersebut yang militan, keras, tegas, hitam putih, tidak menyerah dan tidak segan-segan menggunakan cara-cara yang cendrung anarkhis dan merusak. Di samping itu gerakan radikalisme tersebut juga dipandang tidak mau kompromi serta tidak toleran terhadap kepentingan kelompok lain. Ketiga, dampak dari gerakan radikalisme baik secara langsung maupun tidak langsung dipandang dapat mengancam eksistensi kedudukan para elit penguasa, terutama karena pengaruh agitasi ideologi dan provokasi gerakan radikal yang meluas dalam masyarakat dapat menurunkan tingkat kepercayaan rakyat terhadap rezim penguasa tersebut, yang pada gilirannya dapat melahirkan pembangkangan dan revolusi sosial yang akan meruntuhkan singgasana rezim penguasa.

Seorang peneliti FBI Amerika, Aaronson (2013) menyebutkan, FBI saat ini menghabiskan \$3 miliar setiap tahun untuk memburu musuh yang sebagian besar adalah ciptaannya sendiri. Bukti dalam lusinan kasus terorisme melibatkan pilot untuk meledakkan Sinagog, gedung pencakar langit, stasiun perekrutan militer, dan bar dan klub malam, menunjukkan bahwa teroris hari ini di Amerika Serikat tidak lebih dari kreasi FBI, orang-orang yang mudah dipengaruhi yang hidup di pinggiran masyarakat yang menjadi pemicu bom calon pembunuh hanya karena tindakan informan FBI. FBI dan Departemen Kehakiman kemudian mengutip sengatan ini kasus sebagai bukti bahwa pemerintah 
menghentikan teroris sebelum mereka menyerang. Tetapi bukti yang tersedia untuk ditinjau dalam kasus-kasus ini menunjukkan bahwa "teroris" ini tidak pernah memiliki kemampuan untuk meluncurkan serangan itu sendiri. Sebagian besar target dalam sengatan ini miskin, tidak berpendidikan, dan mudah dimanipulasi.

Kehadiran kelompok gerakan radikal di Jantho Aceh pada tahun 2010 bukti seluruh tokoh Dayah dan ulama di Aceh solid untuk menolak pergerakan sesat yang mengatasnamakan perang suci, dari data tersbut dapat diketahui hanya beberapa yang terlibat dari kalangan masyarakat dan bukan darai kalangan ulama dayah, sehingga dapat dikatakan bahwa jihad memang diajarkan di Dayah namun, pemahaman jihad tidak ada hubungannya dengan tindakan radikal. Untuk itu para ulama dayah berharap kepada seluruh elemen masyarakat untuk belajar mengenal Islam Washatiyah (Islam moderat) agar tidak mudah terpengaruh dengan kelompok gerakan-gerakan radikal. Maka tidak tertutup kemungkinan bahwa gerakan radikal yang sempat berkembang di Aceh merupakan peranakan atau kontra inteligen yang dilakukan oleh kelompok tertentu.

\section{Pemahaman Wahabi Rentan Bersikap Radikal}

Tindakan radikalisme tidak ada hubungannya dengan jihad. kesalahpahaman Wahabi dalam menginterpretasi makna jihad menjadi persoalan tersendiri terhadap pemaknaan jihad, konflik kelompok Aswaja dan Wahabi di Aceh menjadi sesuatu yang memuncak setelah adanya fatwa MPU Aceh No. 9 tahun 2014 tentang "wahabi”. Bustamam (2016: 187) menyebutkan bila menelusuri sejarah kedatangan Islam ke Aceh tidak pernah kita temukan wajah kekerasan. Hampir tidak pernah ada pengalaman kekerasan atas nama agama dalam sejarah awal orang-orang Aceh berhubungan dengan pengembangan agama Islam. Islam telah datang dengan damai dan telah memberikan bukti kongkrit terhadap orang Aceh, karena itulah orang-orang Aceh tidak menganggap Islam sebagai sumber masalah dalam persoalan kekerasan. Namun persoalan penyebaran wahabi di Aceh menjadi sebuah kekhawatiran bagi ulama Aceh yang akan mengubah pola pikir masyarakat Aceh yang sejak Islam datang pertama tidak ada permusuhan.

Menurut Al-Chaidar (2017). Banyak ulama Aceh tradisional yang merasa resah dengan berkembangnya aliran Wahabi yang mengklaim dirinya tak bermazhab ini. Suasana masyarakat yang tadinya guyub dan bersahaja, mulai terbelah ke dalam dua kutub yang saling menganggap dirinya benar. Di kalangan bawah, masyarakat akar rumput bahkan mengalami konflik ini sudah berdarah-darah. Di Sawang, Aceh Utara, terjadi 
penikaman terhadap seorang warga kampung yang mengejek seorang ulama tradisional di kampung tersebut dan rumahnya dibakar warga, di Kabupaten Bireuen Pembakaran Tgk. Ayub, pembakaran Mesjid Muhammaddiyah. Di Banda Aceh terjadi perebutan tongkat dalam tata cara pelaksanaan shalat jum'at. Di internal kalangan Wahabi ini sendiri juga terjadi saling tuding dan saling tuduh sesat menyesatkan. Kalangan Wahabi Shururi sering menuduh Wahabi Jihadi sebagai bughot.

Penyebaran kelompok aliran tersebut telah mengusik keberagaman umat beragama di Aceh selama ini, Wahabi Jihadi lebih banyak pasif dan tak bereaksi secara sosial dan politik. Wahabi Jihadi lebih mengutamakan ibadah-ibadah mahdhoh (ritual) dan menghindari friksi dengan pihak manapun, aktif dalam berbagai acara penyadaran tauhid ummat. Sementara kalangan Wahabi Takfiri sangat hiperaktif dalam dakwahnya dan menuduh banyak kalangan Jihadi sebagai bid'ah, sesat atau kafir terhadap banyak kelompok karena tidak mau menerima khilafah Al-Baghdadi di Suriah dan Iraq. Melalui media sosial kelompok Wahabi Takfiri ini mengumbar seruan-seruannya yang berisik dan penuh ancaman dan tudingan sembari memperlihatkan sikap intolerannya secara asertif.

Radikalisme cenderung di maknai sepihak oleh sekelompok orang tersebut, sehingga dengan mudah disamadkan dengan maksud oleh kelompok itu sendiri, karena jika di kaji lebih konpleks radikalisme itu bukan hanya terjadi dalam sebagian kelompok Islam semata. Di Aceh tidak pernah ada sikap radikalisme yang ada adalah penolakan keras oleh ulama tradisional dayah salafi akan berkembangnya aliran-aliran menyimpang yang cenderung sepontan dalam memahami berbagai persoalan agama seperti wahabi. Sebaliknya yang kelompok itulah dianggap radikal oleh ulama dayah. Karena sejak awal perkembangan dayah di Aceh menjadi benteng pertahanan agar para umat bersatu dan sepaham dalam segala aspek berdasarkan referensi-referensi kitab mu'tabarah (sering digunakan) yang di pelajari di dayah tradisional di Aceh.

\section{KESIMPULAN}

Dalam persfektif Islam dayah radikalisme bukanlah asas jihad, sebaliknya tindakan radikalisme adalah gerakan aliran menyimpang (sesat) yang mengatasnamakan jihad dengan menginterpretasi teks Al-quran secara tertutup. Kelompok fundamentalis radikal tersebut telah mencederai umat Islam. Karen Islam tidak dengan mudah menghalalkan darah manusia meskipun seorang kafir. Paham demikian adalah paham gerakan wahabi yang berani membid'ahkan dan mengkafirkan selain dari kelompok mereka. Islam dayah 
menegaskan Istilah radikalisme dan terorisme adalah samatan oleh golongan anti Islam. Islam agama yang mengajarkan cinta damai dan rukun terhadap umat beragama. Karena itu radikalisme tidak dilakukan oleh yang beragama Islam, namun dilakukan oleh oknum yang mengatasnamakan Islam, selain itu radikalisme juga merupakan ciptaan atau peranakkan oleh sekelompok kepentingan yang ingin mengkotak-kotakkan Islam, bunuh diri tidak ada dalam Islam, bunuh diri adalah paham sesat yang memamfaatkan kebodohan masyarakat awam terhadap pengetahuan tentang Agama. Kebanyakan terikontamidasi dengan pemahaman sesat dalam pergerakan mengatasnamakan jihad. buktinya pergerakan Jama'ah Islamiyah Indonesia yang berkembang di Aceh tahun 2010. Tidak ada ulama Aceh terlibat ketika itu, sebaliknya para ulama mengeluarkan fatwa dan sepakat untuk menolak kehadiran kelompok yang dianggap sesat dan menyimpang di Aceh.

Radikalisme, seolah menjadi kenyataan berdasarkan propaganda Barat tentang islamophobia terhadap Islam, mendistorsi jihad sebagai pemahaman radikal, sehingga pergeseran makna jihad semakin pada titik klimaks dan bersifat negatif. Dalam konteks ini Islam dayah menegaskan tindakan radikal tidak ada kaitan dengan konsep jihad. yang terjadi adalah pemamfaatan teks-tesk jihad yang ditafsirkan secara salah, kemudian di suluti informasi dan pemahaman sesat dari kelompok kepentingan (wahabi) kedalam masyarakat, kelompok ini rentan bersikap radikal. Biasanya mereka bekerja secara terstruktur, masif dan sistematis dalam pergerakan mengatasnamakan jihad. Pandanganpandangan seperti demikian berkembang pada kelompok fundamentalis radikal (khawarij) atau wahabi yang mudah mengkafirkan sesama Islam. 
JISA: Jurnal Ilmiah Sosioologi Agama Prodi Sosiologi Agama Fakultas Ilmu Sosial UIN SU Medan

Vol.2, No.2, November Tahun 2019

\section{DAFTAR PUSTAKA}

Al Chaidar \& Herdi Sahrasad. 2017. Fundamentalisme, Terorisme Dan Radikalisme Perspektif Atas Agama, Masyarakat Dan Negara. Freedom Foundation \& Centre for Strategic Studies - University of Indonesia (CSS-UI)

Abidin Nurdin. 2014. Studi Agama Konsepsi Islam Terhadap Pelbagai Persoalan Kemanusiaan. Bali: Pustaka Larasan.

Alchaidar. 1999. Gerakan Aceh Merdeka; Jihad Rakyat Aceh Mewujudkan negara Islam, Jakarta: Madani Press

Kamaruzzaman Bustamam Ahmad. 2017. Acehnologi, Banda Aceh: Bandar Publishing. 2016. Memahami Potensi Radikalisme dan Terorisme Di Aceh, Banda Aceh: Bandar Publishing. Banda Aceh: KAUKABA.

2005. Ulama, Separtisme dan Radikalisme Di Aceh,

M. Nuh, Nuhrishon. 2009. Faktor-Faktor Penyebab Munculnya Faham/Gerakan Islam Radikal di Indonesia, Jurnal Harmoni, Jurnal Multikultural \& Multireligius Vol. VIII, Juli-September.

Trevor Aaronson. 2013. The Terror Factory. Inside The Fbi's Manufactured War On Terrorism. Library of Congress Cataloging-in-Publication.

Iskandar. 2009. Metodologi Penelitian Kualitatif. Jakarta: Gaung Persada. 